\title{
Gastric Lymphoma
}

National Cancer Institute

\section{Source}

National Cancer Institute. Gastric Lymphoma. NCI Thesaurus. Code C4636.

An extranodal lymphoma that arises from the stomach with the bulk of the mass located in the stomach. The vast majority of cases are diffuse large B-cell lymphomas and B-cell lymphomas of the mucosa-associated lymphoid tissue. 